\title{
MACRONUTRIENT UPTAKE, ACCUMULATION AND EXPORT BY THE IRRIGATED 'VITÓRIA' PINEAPPLE PLANT'(1)
}

\author{
Rodinei Facco Pegoraro(2), Bruna Aparecida Madureira de Souza ${ }^{(3)}$, Victor Martins $^{(2)}$

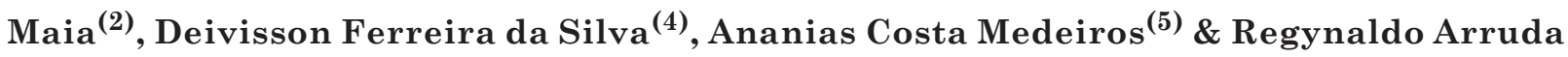 \\ Sampaio $^{(6)}$
}

SUMMARY

The nutritional state of the pineapple plant has a large effect on plant growth, on fruit production, and fruit quality. The aim of this study was to assess the uptake, accumulation, and export of nutrients by the irrigated 'Vitória' pineapple plant during and at the end of its development. A randomized block statistical design with four replications was used. The treatments were defined by different times of plant collection: at $270,330,390,450,510,570,690,750$, and 810 days after planting (DAP). The collected plants were separated into the following components: leaves, stem, roots, fruit, and slips for determination of fresh and dry matter weight at $65^{\circ} \mathrm{C}$. After drying, the plant components were ground for characterization of the composition and content of nutrients taken up and exported by the pineapple plant. The results were subjected to analysis of variance, and non-linear regression models were fitted for the significant differences identified by the $F$ test $(p<0.01)$. The leaves and the stem were the plant components that showed the greatest accumulation of nutrients. For production of $72 \mathrm{t} \mathrm{ha}^{-1}$ of fruit, the macronutrient accumulation in the 'Vitória' pineapple exhibited the following decreasing order: $\mathrm{K}>\mathrm{N}>\mathrm{S}>\mathrm{Ca}>\mathrm{Mg}>\mathrm{P}$, which corresponded to $898,452,134,129,126$, and $107 \mathrm{~kg} \mathrm{ha}^{-1}$, respectively, of total accumulation. The export of macronutrients by the pineapple fruit was in the following decreasing order: $\mathrm{K}>\mathrm{N}>\mathrm{S}>\mathrm{Ca}>\mathrm{P}>\mathrm{Mg}$, which was equivalent to $18,17,11,8,8$, and $5 \%$, respectively, of the total accumulated by the pineapple. The 'Vitória' pineapple plant exported $78 \mathrm{~kg} \mathrm{ha}^{-1}$ of $\mathrm{N}, 8 \mathrm{~kg} \mathrm{ha}^{-1}$ of $\mathrm{P}$, $164 \mathrm{~kg} \mathrm{ha}^{-1}$ of K, $14 \mathrm{~kg} \mathrm{ha}^{-1} \mathrm{of} \mathrm{S,} 10 \mathrm{~kg} \mathrm{ha}^{-1}$ of Ca, and $6 \mathrm{~kg} \mathrm{ha}^{-1}$ of $\mathrm{Mg}$ by the fruit. The

(1) Received for publication on July 10, 2013 and approved on February 27, 2014.

(2) Professor, Department of Agricultural Sciences, Universidade Estadual de Montes Claros, Campus de Janaúba. Av. Reinaldo Viana, 2630, Bico da Pedra. CEP 39440-000, Janaúba (MG), Brazil. E-mail: rodinei_pegoraro@yahoo.com.br, victor.maia@unimontes.br

(3) Master student in Agronomy, Universidade Estadual do Sudoeste da Bahia, Campus Vitória da Conquista. Estrada do Bem Querer, km 4. Caixa Postal 95. CEP 45083-900 Vitória da Conquista (BA), Brazil. E-mail: bruna_madureirasouza@yahoo.com.br

(4) Master student in Agronomy, Universidade Estadual de Montes Claros, Campus de Janaúba. E-mail: f.deivisson@yahoo.com.br, ananias.medeiros@hotmail.com

(5) Graduate Student in Agronomy, Universidade Estadual de Montes Claros, Campus de Janaúba. E-mail: ananias.medeiros@hotmail.com

(6) Associate Professor, Instituto de Ciências Agrárias, Universidade Federal de Minas Gerais. Av. Universitária, 1.000, Bairro Universitário. CEP 39404-547 Montes Claros (MG), Brazil. E-mail: rsampaio@ica.ufmg.br 
nutrient content exported by the fruits represent important components of nutrient extraction from the soil, which need to be restored, while the nutrients contained in the leaves, stems and roots can be incorporated in the soil within a program of recycling of crop residues.

Index terms: Ananas comosus var. comosus, dry matter, uptake rate.

\title{
RESUMO: ABSORÇÃO, ACÚMULO E EXPORTAÇÃO DE MACRONUTRIENTES PELOABACAXIZEIRO 'VITÓRIA' IRRIGADO
}

\begin{abstract}
Oestado nutricional do abacaxizeiro tem grande influência no crescimento de suas plantas e na produção e qualidade de seus frutos. Este estudo teve o objetivo de avaliar a absorção, o acúmulo e a exportação de nutrientes pelo abacaxizeiro 'Vitória', irrigado nas fases de crescimento e produção. O delineamento estatístico utilizado foi em blocos casualizados, com quatro repetições. Os tratamentos foram definidos por distintas épocas de coleta de plantas: 270, 330, 390, 450, 510, 570, 690, 750 e 810 dias após o plantio (DAP). As plantas coletadas foram separadas nos seguintes componentes: folhas, talo, raizes, fruto e mudas, para determinar o peso de matérias fresca e seca a $65^{\circ} \mathrm{C}$. Após secagem, os componentes das plantas foram moídos para caracterizar o teor e conteúdo de nutrientes absorvidos e exportados pelo abacaxizeiro. Os resultados foram submetidos à análise de variância; e para as diferenças significativas, identificadas pelo teste $F(p<0,01)$, foram ajustados os modelos de regressão não linear. As folhas e o talo foram os componentes da planta que apresentaram maior acúmulo de nutrientes. Para a produção de $72 \mathrm{t} \mathrm{ha^{-1 }}$ de frutos, o acúmulo de macronutrientes no abacaxizeiro 'Vitória'evidenciou a seguinte ordem decrescente: $K>N>S>C a>M g>P$ e correspondeu, respectivamente, a 898,452,134, 129, 126 e $107 \mathrm{~kg} \mathrm{ha} \mathrm{h}^{-1}$ de acúmulo total. A exportação de macronutrientes pelo fruto na cultura do abacaxizeiro seguiu a seguinte ordem decrescente: $K>N>S>C a>P>M g$ e equivaleu, respectivamente a 18,17, 11, 8, 8 e $5 \%$ do total acumulado pelo abacaxizeiro. O abacaxizeiro 'Vitória' exportou para o fruto $78 \mathrm{~kg} \mathrm{ha}^{-1}$

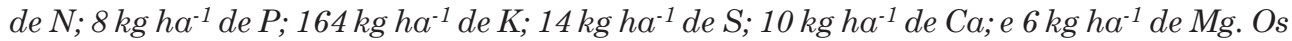
conteúdos de nutrientes exportados pelos frutos representaram importantes componentes de extração de nutrientes do solo, que devem ser restituídos, enquanto os nutrientes contidos nas folhas, no talo e na raiz podem ser incorporados ao solo dentro de um programa de reaproveitamento de restos culturais.
\end{abstract}

Termos de indexação: Ananas comosus var. comosus, matéria seca, marcha de absorção.

\section{INTRODUCTION}

Balanced fertilization for the pineapple plant may be considered one of the main determinants for increased yield, fruit quality, and fruit weight (Amorim et al., 2011). However, for efficient supply of nutrients to the plants, determination of the nutritional demands of the pineapple plant in the different phases of plant vegetative development is of prime importance. According to Grangeiro et al. (2007), one of the tools used in balanced fertilization is nutrient uptake rate, expressed in the form of nutrient uptake curves as a function of the age of the plant.

The nutritional demand of the pineapple plant is high in comparison to other crops and depends on the cultivar, weight of the fruit, and planting density, among other factors (Malézieux \& Bartholomew, 2003; Silva et al., 2009; Teixeira et al., 2011). Studies with traditional cultivars, such as Pérola and Smooth Cayenne, have shown that the pineapple plant takes up an average of 509 to $1,234 \mathrm{~kg} \mathrm{ha}^{-1}$ of $\mathrm{K}, 238$ to $450 \mathrm{~kg} \mathrm{ha}^{-1}$ of N, 161 to $253 \mathrm{~kg} \mathrm{ha}^{-1}$ of Ca,
33 to $157 \mathrm{~kg} \mathrm{ha}^{-1}$ of $\mathrm{Mg}, 13$ to $75 \mathrm{~kg} \mathrm{ha}^{-1}$ of $\mathrm{P}$, and 17 to $40 \mathrm{~kg} \mathrm{ha}^{-1}$ of S (Hiroce et al., 1977; Py et al., 1987). Furthermore, according to Paula et al. (1985), the fruits and slips of the Pérola cultivar exported around $16 \%$ of the $\mathrm{K}$ and $\mathrm{N}, 13 \%$ of the $\mathrm{Ca}, 9 \%$ of the $\mathrm{Mg}$, and $22 \%$ of the $\mathrm{S}$ accumulated by the plant.

The 'Vitória' pineapple plant may be considered a cultivar that has agronomic characteristics similar or superior to the cultivars Pérola and Smooth Cayenne, whose fruits may be directed to the market for in natura consumption and to the agro-industrial sector (Ventura et al., 2009). However, information in respect to nutritional demands is still quite recent (Baldotto et al., 2009), leading to unbalanced use of fertilizers, possible yield losses, and low return on investment for rural producers. According to Ribeiro et al. (2011), the nutritional state of the pineapple plant greatly affects plant growth and, consequently, fruit yield and quality.

Nutrient uptake by the pineapple plant is related to its phenological cycle and may be characterized as an initial phase of vegetative growth and slow uptake of nutrients, which occurs from the time of transplant 
of plantlets up to the first six months of growth, followed by a second phase, after six months of growth, with successive increases in nutrient uptake and biomass production up to induced flowering of the pineapple plant, the time at which translocation of nutrients and photoassimilates from the vegetative organs to the fruits begins. According to Malézieux \& Bartholomew (2003), the pineapple plant has low demand for $\mathrm{N}$ and $\mathrm{K}$ in the first three months after planting, after which the need increases up to the time of induced flowering.

Regional climate conditions and factors linked to crop management, such as the plant species, use of irrigation, and size of the plantlets, have a direct effect on the phenological cycle and nutrient uptake by the pineapple plant. Knowledge of the amounts of nutrients accumulated in the plant at each stage of development is of prime importance for complementing strategies of definition of amounts and times of crop fertilization and of the minimum amounts that need to be restored to the soil to maintain fertility (Py et al., 1987; Grangeiro et al., 2007).

Determination of nutrient accumulation in the separate components of the plant becomes necessary for determining the phase of maximum uptake by these components and for showing the redistribution of nutrients in favor of the fruit. That way, balanced fertilization provides adequate nutrition, contributing to maximum expression of plant potential (Augostinho et al., 2008). Therefore, knowing the aspects related to mineral nutrition of the pineapple plant is fundamental to achieve success in growing. Among other aspects, nutrient accumulation is essential for defining crop fertilization strategies (Silva et al., 2009).

Studies related to uptake capacity and accumulation and export of nutrients by the 'Vitória' pineapple crop are relatively rare, especially because of the shorter time the cultivar has been on the market. Thus, the aim of this study was to assess the uptake, accumulation, and export of nutrients by the irrigated 'Vitória' pineapple plant in the north of the State of Minas Gerais, Brazil.

\section{MATERIALS AND METHODS}

The study was carried out from July 2009 to October 2011 under field conditions in the municipality of Janaúba, MG, Brazil, located at $15^{\circ} 43^{\prime} 47.4^{\prime \prime} \mathrm{S}$ and $43^{\circ} 19^{\prime} 22.1^{\prime \prime} \mathrm{W}$, at an altitude of $516 \mathrm{~m}$. Climate in the region, according to the Köppen classification, is "Aw" (hot tropical with cool and dry winter), with mean rainfall of approximately $870 \mathrm{~mm}$, mean annual temperature of $24^{\circ} \mathrm{C}$, sunlight of 2,700 $\mathrm{h}$ annually, and mean relative humidity of $65 \%$. Soil in the experimental area was classified as a Latossolo Vermelho eutrófico (Embrapa, 2006) [Oxisol]. The mean data in regard to maximum and minimum temperatures and to rainfall during the time of the study are described in figure 1 (INMET, 2012).

Pineapple plantlets of the 'Vitória' cultivar, resulting from the cross between the cultivars 'Primavera' and 'Smooth Cayenne', were multiplied in the laboratory by micropropagation and then transplanted in the experimental area after reaching a mean height of 15 to $20 \mathrm{~cm}$. A randomized block experimental design with four replications was used. The treatments were defined by time, in days after planting (DAP), with the collection times of the plants being determined according to the development cycle of the pineapple crop, which in this study ended at 810 DAP. In this study, there were a total of nine collections: at $270,330,390,450,510,570,690,750$ and $810 \mathrm{DAP}$. The first collection was made late, due to the small size of the micropropagated plantlets.

Soil tillage consisted of disking and creation of plant furrows. For physical-chemical characterization of the soil (Embrapa, 1997) in the crop area, 20 simple samplings were made to obtain a compound sample from the $0-20 \mathrm{~cm}$ layer, with the following results: $\mathrm{pH}\left(\mathrm{H}_{2} \mathrm{O}\right)=5.40 ; \mathrm{P}=3.70 \mathrm{mg} \mathrm{dm}^{-3}$ and $\mathrm{K}=72.00$ $\mathrm{mg} \mathrm{dm}{ }^{-3}$ (Mehlich-1); $\mathrm{Al}^{3+}=0.30 \mathrm{cmol}_{\mathrm{c}} \mathrm{dm}^{-3}, \mathrm{Ca}^{2+}=1.30$ $\mathrm{cmol}_{\mathrm{c}} \mathrm{dm}^{-3}$, and $\mathrm{Mg}^{2+}=0.50 \mathrm{cmol}_{\mathrm{c}} \mathrm{dm}^{-3}\left(1 \mathrm{~mol} \mathrm{~L}^{-1}\right.$ $\mathrm{KCl}) ; \mathrm{H}+\mathrm{Al}=1.80 \mathrm{cmol}_{\mathrm{c}} \mathrm{dm}^{-3}\left(0.5 \mathrm{~mol} \mathrm{~L}^{-1}\right.$ calcium acetate, $\mathrm{pH} 7.0) ; \mathrm{B}=0.3 \mathrm{mg} \mathrm{dm}^{-3}, \mathrm{Zn}=0.50 \mathrm{mg} \mathrm{dm}^{-3}$, $\mathrm{Cu}=0.50 \mathrm{mg} \mathrm{dm}^{-3}, \mathrm{Fe}=31.30 \mathrm{mg} \mathrm{dm}^{-3}$, and $\mathrm{Mn}=$ $5.30 \mathrm{mg} \mathrm{dm}^{-3}$ (Mehlich-1); $\mathrm{CO}=5.3 \mathrm{~g} \mathrm{~kg}^{-1}$ (WalkleyBlack); and clay $=270 \mathrm{~g} \mathrm{~kg}^{-1}$. Recommendation of fertilization was adapted from Souza et al. (1999) using the application rate of $16.7 \mathrm{~g} / \mathrm{plant}$ of the fertilizer simple superphosphate at planting, distributed in the furrows. With a view toward increasing the availability of $\mathrm{Ca}$ and $\mathrm{Mg}$ in the soil for the pineapple crop, we chose to apply $500 \mathrm{~kg} \mathrm{ha}^{-1}$ of calcium and

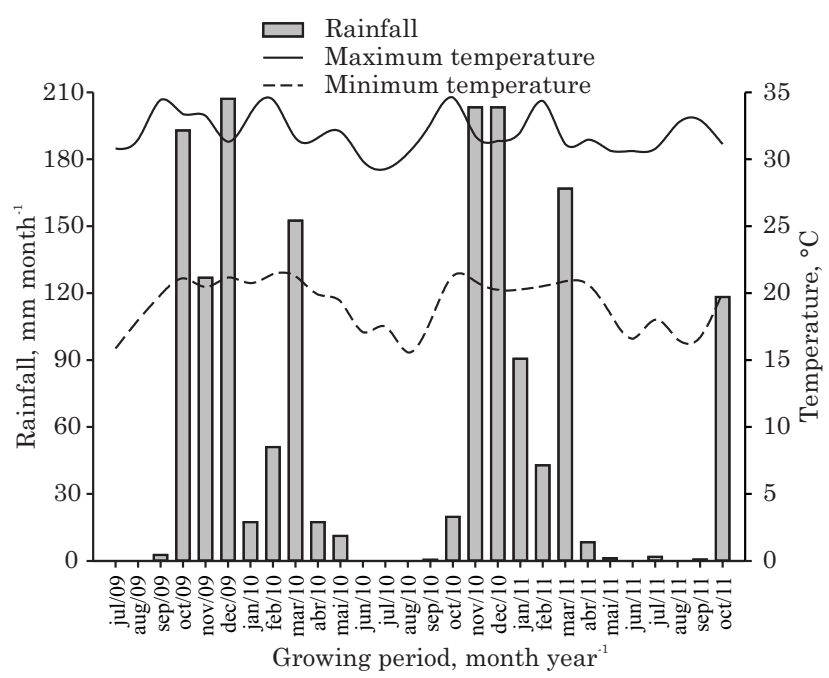

Figure 1. Rainfall, monthly maximum and minimum temperature obtained in the municipality of Janaúba, MG, Brazil, for the growing period of the 'Vitória' pineapple plant (07/2009 to 10/2011). 
magnesium silicate (Agrosilício®, with $34.9 \% \mathrm{CaO}$, $9.9 \% \mathrm{MgO}$, and $22.4 \% \mathrm{SiO}_{2}$ ).

The plantlets were transplanted in the furrows, in a double-row system, at a spacing of $0.90 \times 0.40 \times$ $0.30 \mathrm{~m}$, resulting in a density of 51,280 plants $^{-1}$. Each plot was composed of two double rows, for a total of 48 plants per plot. At the time of assessment, the border area was not considered, with only 20 plants remaining in each useful area.

Surface application of fertilizer was divided into six portions, in the months of January, May, July, September, and November 2010, and February 2011, the period that preceded the beginning of induced flowering of the pineapple plant. The purpose of apportioned application of fertilizer was to increase the efficiency of $\mathrm{N}$ and $\mathrm{K}$ uptake by the irrigated pineapple plant. Total application was $15 \mathrm{~g} /$ plant of $\mathrm{N}$ and $\mathrm{K}_{2} \mathrm{O}$ using urea and potassium chloride as sources, respectively, applied in the plant row and incorporated with the use of irrigation water. Foliar feedings were also carried out with $0.07 \%$ de B, $0.1 \%$ $\mathrm{Zn}$, and $0.1 \% \mathrm{Cu}$, in the forms of boric acid, zinc sulfate, and copper sulfate, respectively, applied in the same period of fertilization carried out for $\mathrm{N}$ and $\mathrm{K}$.

In the first 12 months of growth, weed control was carried out manually. After that, we chose chemical control up to the flowering phase with the use of Gesapax 500 (200 $\mathrm{mL} \mathrm{L}^{-1}$ of water) and Verdict $\mathrm{R}\left(100 \mathrm{~mL} \mathrm{~L}{ }^{-1}\right.$ of water) for control of broadleaf weeds and grass(like) weeds, respectively. After induced flowering, weed control was performed manually once more.

Flowering was induced at 630 days after planting with $50 \mathrm{~mL}$ of $\mathrm{Ethrel}^{\circledR}$ solution at $1 \%$, with the addition of calcium hydroxide (lime) at the rate of $0.35 \mathrm{~g} \mathrm{~L}^{-1}$ of water (Reinhardt et al., 2001). Irrigation was suspended $24 \mathrm{~h}$ before induced flowering so as to obtain greater effectiveness and uniformity in flowering. With a view toward reducing fruit burn as a result of solar radiation, the fruits were protected with newspaper at 60 days after induced flowering. The fruits were harvested when they had at least $50 \%$ yellow peel.

The plants collected in each sampling period were taken to the Soil Laboratory where their components were separated into roots, stem, fruit, and slips for weighing fresh matter. Weights were also determined for dry matter of vegetative biomass (sum of the mean weight of dry matter of leaves, roots, and stems) and total biomass (sum of the mean weight of vegetative biomass, fruit, and slips) in t ha ${ }^{-1}$. The components of the pineapple plant were dried in an air-circulation laboratory oven $\left(65^{\circ} \mathrm{C}\right)$ for about $72 \mathrm{~h}$, and after the material reached constant weight, the dry matter weight of all the previously cited components of the pineapple plant was determined.

A fixed conventional sprinkler irrigation system was used with Agropole NY 25 nozzles and nominal flow of $500 \mathrm{~L} \mathrm{~h}^{-1}$. The spacing between emitters was $12 \mathrm{~m}$ along a lateral line, with line spacing of $12 \mathrm{~m}$. Three irrigations were carried out per week for variable lengths of time depending on the growth phase of the pineapple and natural rainfall.

During the period of the study and for each sampling period, accumulations of $\mathrm{N}, \mathrm{P}, \mathrm{K}, \mathrm{Ca}, \mathrm{Mg}$, and $\mathrm{S}$, in $\mathrm{kg} \mathrm{ha}^{-1}$, in the different components of the Vitória pineapple plant, vegetative biomass, and total biomass were determined.

The $\mathrm{N}$ contents were obtained by nitric-perchloric digestion by the Kjeldahl method, $\mathrm{P}$ by colorimetry, $\mathrm{Ca}$ and $\mathrm{Mg}$ by atomic absorption spectrophotometry, $\mathrm{K}$ by flame emission photometry, and $\mathrm{S}$ by turbidimetry, as suggested by Malavolta et al. (1997). Total N contents were determined by the Kjeldahl method. The accumulation of each nutrient for the respective plant components was calculated by the mathematical expression described below:

$$
\text { Accumulation }=\frac{\mathrm{DMxC}}{100}
$$

in which, Accumulation: accumulation of nutrients in the plant compartment ( $\left.\mathrm{kg} \mathrm{ha}^{-1}\right)$; DM: dry matter in the plant compartment $(\mathrm{kg})$; and $\mathrm{C}$ : nutrient content in the plant compartment $\left(\mathrm{dag} \mathrm{kg}^{-1}\right)$.

The data were subjected to analysis of variance by the Sisvar ${ }^{\circledR}$ statistical analysis software and, when significant for the sources of variation $(p<0.01)$, the effects of days after planting on the growth and development of the plants were studied by regression analysis, choosing the adequate model to represent them.

The choice of the models occurred according to the appropriateness of fit (percentage of variance explained, $R^{2}$ ) and best representation of the phenomenon. The non-linear regression models chosen for representation of the accumulation of nutrients in the plant and in its different compartments were the sigmoid and the Gaussian. The sigmoid model with three parameters is shown in the equation below:

$$
\hat{y}=\frac{a}{1+e\left[-0.5\left(\frac{x-x_{0}}{b}\right)\right]}
$$

in which, a: corresponds to the maximum accumulation value; $\mathrm{x}_{0}$ : corresponds to the value of $\mathrm{x}$, in DAP for the beginning of the inflection of the curve (inflection point, where there is the maximum rate of accumulation of nutrients); and b: corresponds to the amplitude in the value of $\mathrm{x}$, in DAP, in which there is the greatest variation of $y$ (accumulation of nutrients).

The Gaussian regression model with three parameters is shown in the equation below:

$$
\hat{y}=a e\left[-0.5\left(\frac{x-x_{0}}{b}\right)^{2}\right]
$$


in which, a: corresponds to the maximum accumulation value, $\mathrm{x}_{0}$ : corresponds to the value of $\mathrm{x}$, in DAP, to obtain maximum accumulation of nutrients; and b: corresponds to the amplitude in the value of $x$, in DAP, between the inflection point and the maximum point.

Thus, from the fitted model, it was possible to precisely determine the value of the inflection point (IP) on the curve in the following manner: $I P=X o-b$.

Mathematically, the IP corresponds to the value of $x$ at which the curvature of the fitted model changes signs; in practice, this corresponds to the value of $x$, in DAP, at which the daily accumulation rate, even though positive, starts to decrease.

By these fitted models, it was possible to estimate the maximum accumulation rate (MAR) in $\mathrm{kg} \mathrm{ha}^{-1}$ day $^{-1}$, which corresponded to the beginning of inflection of the curve of nutrient accumulation in the components and of the plant as a function of DAP.

\section{RESULTS AND DISCUSSION}

The macronutrient content taken up by the 'Vitória' pineapple plant and its components (leaves, stem, roots, vegetative biomass, and total biomass) was significantly affected $(\mathrm{p} \leq 0.05)$ by growing time.

At the end of the 'Vitória' pineapple plant crop cycle to obtain mean yield of $72 \mathrm{t} \mathrm{ha}^{-1}$ of fruit, the following decreasing order of total accumulation of macronutrients was observed: $898 \mathrm{~kg} \mathrm{ha}^{-1}$ of $\mathrm{K}$, $452 \mathrm{~kg} \mathrm{ha}^{-1}$ of N, $134 \mathrm{~kg} \mathrm{ha}^{-1}$ of S, $129 \mathrm{~kg} \mathrm{ha}^{-1}$ of Ca, $126 \mathrm{~kg} \mathrm{ha}^{-1}$ of $\mathrm{Mg}$, and $107 \mathrm{~kg} \mathrm{ha}^{-1}$ of $\mathrm{P}$, indicating greater $\mathrm{N}$ and $\mathrm{K}$ demand by the crop in comparison to other macronutrients, as indicated by Teixeira et al. (2011). The 'Vitória' pineapple plant expressed intermediate capacity for taking up macronutrients in comparison to other studies undertaken with the cultivars Pérola and Smooth Cayenne, which showed mean accumulation ranging from $509-1,234 \mathrm{~kg} \mathrm{ha}^{-1}$ of K, 238-450 kg ha-1 of N, 161-253 kg ha-1 of Ca, 33$157 \mathrm{~kg} \mathrm{ha}^{-1}$ of Mg, $13-75 \mathrm{~kg} \mathrm{ha}^{-1}$ of $\mathrm{P}$, and 17-40 $\mathrm{kg} \mathrm{ha}^{-1}$ of S (Hiroce et al., 1977; Py et al., 1987).

The macronutrient content in the 'Vitória' pineapple plant in the phase of induced flowering, assessed by comparison between the macronutrient content in leaf ' $\mathrm{D}$ ' $\left(\mathrm{K}=2.41 \mathrm{dag} \mathrm{kg}{ }^{-1}, \mathrm{~N}=1.34 \mathrm{dag} \mathrm{kg}^{-1}\right.$, $\mathrm{P}=0.60 \mathrm{dag} \mathrm{kg}^{-1}, \mathrm{Mg}=0.42 \mathrm{dag} \mathrm{kg}^{-1}, \mathrm{Ca}=0.29$ dag $\mathrm{kg}^{-1}, \mathrm{~S}=0.20 \mathrm{dag} \mathrm{kg}^{-1}$ ) and the reference standard (Martinez et al., 1999), was considered adequate. Nevertheless, Ramos et al. (2011), for the 'Imperial' pineapple plant, observed the following leaf contents: $\mathrm{K}=2.00, \mathrm{~N}=1.5, \mathrm{Ca}=0.44, \mathrm{Mg}=0.23, \mathrm{~S}=0.15$, and $\mathrm{P}=0.12 \mathrm{dag} \mathrm{kg}^{-1}$ and, for the cultivar Smooth Cayenne, Marques et al. (2013), assessing application rates and apportionment of $\mathrm{N}$ on macronutrient contents, obtained mean contents of $\mathrm{K}$ above 3.15 dag $\mathrm{kg}^{-1}$ and of $\mathrm{P}$ below $0.20 \mathrm{dag} \mathrm{kg}^{-1}$, indicating the need for standardization of recommendations of leaf contents adequate for each commercial cultivar of the pineapple plant.

The intensity of uptake, assessed by the rate of macronutrient uptake by the pineapple plant, was low in the initial phase of growth, coinciding with the period of lower accumulation of dry matter. In the vegetative components of the plant, initial uptake of nutrients was also considered slow; nevertheless, after 450 DAP, there was intensification in accumulation of macronutrients by the leaves, roots, and stem up to the beginning of the reproductive period of the pineapple plant, which corresponded approximately to 660 DAP (Table 1). According to Malézieux \& Bartholomew (2003), the pineapple plant has low demand for $\mathrm{N}$ and $\mathrm{K}$ in the first three months after planting. After that, the need increases up to the time of induced flowering.

Maximum accumulation of $\mathrm{N}$ in the pineapple plant (total biomass) was observed at approximately 680 DAP and corresponded to $403.95 \mathrm{~kg} \mathrm{ha}^{-1}$. Maximum accumulation for the other components - leaves, stem, roots, and vegetative biomass of the plant - occurred at 665, 765, 667, and 679 DAP, respectively (Table 1). Nevertheless, the rates of maximum accumulation of $\mathrm{N}$, which indicate the phase of greatest nutritional demand in the whole plant, vegetative biomass, leaves, stem, and roots, occurred at 519, 549, 543, 601, and 537 DAP, respectively, and were $2,689,1,944,1,695,310$, and $34 \mathrm{~g} \mathrm{ha}^{-1}$ day $^{-1}$. Such observations indicated that the period of greatest $\mathrm{N}$ demand by the 'Vitória' pineapple plant occurred from 519 to 601 DAP, growth phases that precede and draw near the time of induced flowering of the pineapple plant. It should be noted that, as of these growth periods, the use of $\mathrm{N}$ fertilization on the pineapple plant would show less effectiveness in increasing the yield and quality of the fruits.

Uptake of $\mathrm{P}$ during the growth of the 'Vitória' pineapple plant fitted models similar to those found for $\mathrm{N}$; nevertheless, $\mathrm{P}$ was the macronutrient least taken up by the pineapple plant, with $99.15 \mathrm{~kg} \mathrm{ha}^{-1}$ of accumulation in the plant at 541 DAP (Table 1), and the leaves were the organ responsible for accumulation of more than $90 \%$ of the P taken up by the plant, indicating the importance of this organ in redistribution of $\mathrm{P}$ to the reproductive components of the pineapple plant after induced flowering. The period of greatest demand of $\mathrm{P}$ (maximum accumulation rate) by the pineapple plant occurred from 498 to 675 DAP and corresponded to $424,54,1,1643$, and $1528 \mathrm{~g} \mathrm{ha}^{-1}$ day $^{-1}$ in the leaves, stem, roots, vegetative biomass, and total biomass, respectively.

Potassium was the nutrient required in greatest quantities by the pineapple plant, which was in agreement with Teixeira et al. (2011). Maximum accumulation of $\mathrm{K}$ in the plant was $1,404.25 \mathrm{~kg} \mathrm{ha}^{-1}$ and occurred at $775 \mathrm{DAP}$, and the greatest demand 
for $\mathrm{K}$, expressed by the greater rates of maximum accumulation in the plant and its components of leaves, stem, and roots, occurred from 550 to 775 DAP (Table 1), indicating, as for $\mathrm{N}$, that the greatest demand for $\mathrm{K}$ by the pineapple plant occurs in the period before induced flowering, with greater rates of $\mathrm{K}$ being recommended in that period. Various studies reported the importance of balanced nutrition with $\mathrm{K}$ in the pineapple plant for ensuring a rise in total soluble solids content and vitamin $\mathrm{C}$ in the fruit,

Table 1. Estimate of the parameters of the fitted non-linear regression model and maximum accumulation rate (MAR) of macronutrients in the plant components: roots, stem, leaves, vegetative biomass, and total biomass during the development cycle of the 'Vitória' pineapple plant. Inflection point (IP) indicates the value of $x$, in DAP, in which the daily rate of accumulation, though positive, begins to decrease

\begin{tabular}{|c|c|c|c|c|c|c|}
\hline \multirow{2}{*}{ Plant part } & \multicolumn{3}{|c|}{ Estimate of the fitted model ${ }^{(1)}$} & \multirow{2}{*}{ IP } & \multirow{2}{*}{$\mathbf{R}^{2}$} & \multirow{2}{*}{ MAR } \\
\hline & $\mathbf{a}$ & $\mathbf{x}_{0}$ & $\mathbf{b}$ & & & \\
\hline & $\mathrm{kg} \mathrm{ha} \mathrm{H}^{-1}$ & + & $-\mathrm{DAP}-$ & 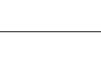 & & $\mathrm{g} \mathrm{ha}^{-1}$ day $^{-1}$ \\
\hline & & & Nitrogen & & & \\
\hline $\operatorname{Root}^{(2)}$ & $7.36^{*}$ & $666.76^{*}$ & $129.33^{*}$ & 537.43 & 0.86 & 34.27 \\
\hline Stem $^{(2)}$ & $83.32^{*}$ & $764.48^{*}$ & $163.05^{*}$ & 601.43 & 0.96 & 309.93 \\
\hline Leave $^{(2)}$ & $341.28 *$ & $664.95^{*}$ & $122.13^{*}$ & 542.82 & 0.92 & $1,694.75$ \\
\hline Vegetative biomass ${ }^{(2)}$ & $418.01^{*}$ & $678.93^{*}$ & $130.43^{*}$ & 548.50 & 0.95 & $1,943.67$ \\
\hline \multirow[t]{2}{*}{ Total biomass ${ }^{(3)}$} & $403.95^{*}$ & $519.07^{*}$ & $37.55^{*}$ & 519.07 & 0.95 & $2,689.14$ \\
\hline & & & Phosphorus & & & \\
\hline $\operatorname{Root}^{(2)}$ & $0.34^{*}$ & $651.13^{*}$ & $153.42^{*}$ & 497.71 & 0.71 & 1.34 \\
\hline Stem $^{(3)}$ & $18.39^{*}$ & $675.23^{*}$ & $84.94^{*}$ & 675.23 & 0.99 & 54.14 \\
\hline Leave $^{(2)}$ & $91.44^{*}$ & $705.63^{*}$ & $130.53^{*}$ & 575.10 & 0.88 & 424.28 \\
\hline Vegetative biomass ${ }^{(3)}$ & $92.41^{*}$ & $536.06^{*}$ & $14.06^{*}$ & 536.06 & 0.99 & $1,642.64$ \\
\hline \multirow[t]{2}{*}{ Total biomass ${ }^{(3)}$} & $99.15^{*}$ & $541.17^{*}$ & $16.22^{*}$ & 541.17 & 0.99 & $1,527.95$ \\
\hline & & & Potassium & & & \\
\hline $\operatorname{Root}^{(2)}$ & $5.46^{*}$ & $704.09 *$ & $153.97^{*}$ & 550.12 & 0.61 & 21.52 \\
\hline Stem $^{(2)}$ & $132.55^{*}$ & $777.43^{*}$ & $124.99 *$ & 652.44 & 0.99 & 643.19 \\
\hline Leave $^{(2)}$ & $411.24^{*}$ & $738.12^{*}$ & $174.25^{*}$ & 563.87 & 0.94 & $1,431.34$ \\
\hline Vegetative biomass ${ }^{(2)}$ & $540.52 *$ & $757.75^{*}$ & $172.73^{*}$ & 585.02 & 0.97 & $1,897.93$ \\
\hline \multirow[t]{2}{*}{ Total biomass ${ }^{(3)}$} & $1,404.25^{*}$ & $774.57^{*}$ & $136.32^{*}$ & 774.57 & 0.95 & $2,575.21$ \\
\hline & & & Sulfur & & & \\
\hline $\operatorname{Root}^{(2)}$ & $1.31^{*}$ & $735.45^{*}$ & $206.68^{*}$ & 528.77 & 0.74 & 3.83 \\
\hline Stem $^{(3)}$ & $56.20^{*}$ & $688.82^{*}$ & $98.64^{*}$ & 688.82 & 0.98 & 142.44 \\
\hline Leave $^{(2)}$ & $60.80^{*}$ & $723.19^{*}$ & $148.35^{*}$ & 574.84 & 0.90 & 248.57 \\
\hline Vegetative biomass ${ }^{(2)}$ & $96.10^{*}$ & $800.76^{*}$ & $191.13^{*}$ & 609.63 & 0.93 & 304.95 \\
\hline \multirow[t]{2}{*}{ Total biomass $^{(3)}$} & $158.81^{*}$ & $680.69^{*}$ & $112.15^{*}$ & 680.69 & 0.93 & 279.51 \\
\hline & & & Calcium & & & \\
\hline $\operatorname{Root}^{(2)}$ & $1.33^{*}$ & $775.47^{*}$ & $237.72^{*}$ & 537.75 & 0.80 & 3.40 \\
\hline Leave $^{(3)}$ & $55.49 *$ & $443.95^{*}$ & $36.13^{*}$ & 443.95 & 0.91 & 19.00 \\
\hline Vegetative biomass ${ }^{(3)}$ & $85.80^{*}$ & $469.88^{*}$ & $60.95^{*}$ & 469.88 & 0.89 & 351.92 \\
\hline \multirow[t]{2}{*}{ Total biomass ${ }^{(3)}$} & $119.10 *$ & $557.08^{*}$ & $115.02 *$ & 557.08 & 0.85 & 258.92 \\
\hline & & & Magnesium & & & \\
\hline $\operatorname{Root}^{(2))}$ & $0.37 *$ & $578.60^{*}$ & $173.00^{*}$ & 405.60 & 0.64 & 1.33 \\
\hline Stem $^{(3)}$ & $138.19^{*}$ & $557.63^{*}$ & $25.12^{*}$ & 557.63 & 0.92 & 8.95 \\
\hline Leave $^{(2)}$ & $169.75^{*}$ & $697.07^{*}$ & $102.70^{*}$ & 594.37 & 0.97 & $1,002.51$ \\
\hline Vegetative biomass ${ }^{(2)}$ & $194.73^{*}$ & $626.71^{*}$ & $97.71^{*}$ & 529.00 & 0.94 & $1,208.67$ \\
\hline Total biomass ${ }^{(2)}$ & $193.68^{*}$ & $631.77^{*}$ & $102.41^{*}$ & 529.36 & 0.93 & $1,147.07$ \\
\hline
\end{tabular}

*: significant at $5 \%$ by the $\mathrm{F}$ test. ${ }^{(1)}$ a: corresponds to the maximum accumulation value; $\mathrm{x}_{0}$ : in the sigmoid model corresponds to the DAP for beginning of inflection of the curve (inflection point, where the maximum rate of nutrient accumulation occurs) and, in the Gaussian model corresponds to the DAP for obtaining the maximum accumulation of the nutrient; b: in the sigmoid model, corresponds to the amplitude of DAP in which the greatest variation in accumulation of the nutrient occurs and, in the Gaussian corresponds to the amplitude of DAP between the inflection point and the point of maximum accumulation. ${ }^{(2)}$ Fitted with non-linear sigmoid model. ${ }^{(3)}$ Fitted with non-linear Gaussian model. 
increasing fruit quality (Spironello et al., 2004; Baafi et al., 2009; Guarçoni \& Ventura, 2011).

The maximum accumulation of sulfur obtained by the pineapple plant (total biomass) was $159 \mathrm{~kg} \mathrm{ha}^{-1}$ at 681 DAP, and the phases of greatest demand for sulfur occurred from 528 to 610 DAP. The maximum rate of daily accumulation was $305,249,142$, and $4 \mathrm{~g} \mathrm{ha}^{-1}$ day $^{-1}$ for vegetative biomass, leaves, stem, and roots, respectively (Table 1), indicating that the leaves were the main drain of $S$ in the vegetative phase of the pineapple plant, as for the other macronutrients.

The accumulation curves of $\mathrm{Ca}$ and $\mathrm{Mg}$ in the vegetative period (vegetative biomass) exhibited similar behavior because the inflection point for accumulation of these nutrients occurred from 470 to 529 DAP (Table 1). In this period, the maximum rate of accumulation of $\mathrm{Ca}$ and $\mathrm{Mg}$ was 351, 92, and 1,208.67, respectively, indicating greater intensity of uptake of Mg by the 'Vitória' pineapple plant and the high demand for this nutrient by the crop. Studies carried out with various pineapple cultivars in Brazil indicate a leaf ratio of $\mathrm{Ca}: \mathrm{Mg}$ in the induced flowering phase near 1 (one) (Coelho et al., 2007; Sampaio et al., 2011), which confirms the high demand for $\mathrm{Mg}$ by the pineapple plant.

In spite of possible stabilization in Ca uptake by the vegetative organs of the plant (leaves, stem, and roots) in the induced flowering phase, after this period, an increase was observed in Ca uptake by the plant (total biomass) (Table 1) due to its accumulation in the reproductive organs (fruit and slips), indicating the continuity of $\mathrm{Ca}$ uptake derived from the soil solution after induced flowering, possibly brought about by lower capacity of translocation of this nutrient in the plant from the vegetative organs to the reproductive ones.

In $\mathrm{Mg}$ uptake, maximum accumulation in the plant occurred at 632 DAP and corresponded to $193.68 \mathrm{~kg} \mathrm{ha}^{-1}$ (Table 1), this date corresponding to the beginning of the reproductive period of the pineapple plant, which demonstrated that, as of induced flowering, $\mathrm{Mg}$ was probably translocated with greater intensity from the vegetative organs, especially the leaves (responsible for accumulation of more than $80 \%$ of the $\mathrm{Mg}$ of the plant), to the reproductive organs.

In the pineapple crop, the fruits constituted the main route of export of nutrients. For mean pineapple production of $71.77 \mathrm{t} \mathrm{ha}^{-1}$, there was export of $\mathrm{K}, \mathrm{N}$, $\mathrm{S}, \mathrm{Ca}, \mathrm{P}$, and $\mathrm{Mg}$ in the order of $163.95,77.51,14.41$, $10.30,8.34$, and $6.33 \mathrm{~kg} \mathrm{ha}^{-1}$, respectively. This represented, in percentage, $18,17,11,8,8$, and $5 \%$ of the accumulated total of macronutrients in the 'Vitória' pineapple plant. The export of nutrients also occurred through propagative material (slips and suckers) for planting in other areas. Export of K, N, $\mathrm{Ca}, \mathrm{S}, \mathrm{P}$, and $\mathrm{Mg}$ through plantlets corresponded to 126.26, 67.81, 17.18, 13.06, 7.55, and $6.41 \mathrm{t} \mathrm{ha}^{-1}$, respectively, which represents, in terms of percentage, $14,15,13,10,7$, and $5 \%$ of the accumulation of these respective macronutrients in the whole plant (total biomass) of the 'Vitória' pineapple plant.

Nitrogen and K were the macronutrients that were most exported by the fruits and plantlets; however, approximately $70 \%$ of the accumulated total of nutrients are subject to return to the soil through crop residues of leaves, stem, and roots of the pineapple plant, and they may then be mineralized and taken up by subsequent crops. Nahrawi et al. (2011) indicated, after 14 months of incubation of leaf and root residues $(<3 \mathrm{~mm})$ on the soil surface of the pineapple crop, in 'litterbags', decomposition greater than 90 and $50 \%$, respectively, for the region of Johor in Malaysia, and, at 210 days after deposition, more than $80 \%$ of the leaf residues were decomposed, indicating the high potential of mineralization of nutrients from the leaves of the pineapple plant as a source of nutrients for other crops. It should be highlighted that the mineralization rate of nutrients in pineapple plant residues on the soil is dependent, among other factors, on the crop and soil management system, as well as local climate conditions. For the regional condition of a semi-arid climate, it is believed that high mean annual temperatures, together with irrigated crop systems, intensify the decomposition rate of plant residues.

\section{ACKNOWLEDGMENT}

The authors thank the FAPEMIG (Fundação de Amparo à Pesquisa do Estado de Minas Gerais/Minas Gerais State Research Foundation) for funding the research Project.

\section{CONCLUSIONS}

1. The accumulation of macronutrients in the 'Vitória' pineapple plant exhibit the following decreasing order: $\mathrm{K}>\mathrm{N}>\mathrm{S}>\mathrm{Ca}>\mathrm{Mg}>\mathrm{P}$, and correspond to $898.32 \mathrm{~kg} \mathrm{ha}^{-1}$ of $\mathrm{K}, 451.71 \mathrm{~kg} \mathrm{ha}^{-1}$ of $\mathrm{N}, 134.27 \mathrm{~kg} \mathrm{ha}^{-1}$ of S, $129.17 \mathrm{~kg} \mathrm{ha}^{-1}$ of Ca, 126.41 $\mathrm{kg} \mathrm{ha}^{-1}$ of $\mathrm{Mg}$, and $107.26 \mathrm{~kg} \mathrm{ha}^{-1}$ of $\mathrm{P}$.

2 . The mobile macronutrients in the plant, $\mathrm{N}, \mathrm{P}$, $\mathrm{K}$, and $\mathrm{Mg}$, exhibit their point of maximum accumulation and sharp increases in uptake by the pineapple plant in periods prior to and at induced flowering, from 450 to $600 \mathrm{DAP}$, indicating that fertilization with $\mathrm{N}$ and $\mathrm{K}$ need to be apportioned in greater applications in periods prior to induced flowering.

3. The export of macronutrients by the fruit in the pineapple crop are in the following decreasing order: $\mathrm{K}>\mathrm{N}>\mathrm{S}>\mathrm{Ca}>\mathrm{P}>\mathrm{Mg}$, which is $163.95 \mathrm{~kg} \mathrm{ha}^{-1}$ of 
$\mathrm{K}, 77.51 \mathrm{~kg} \mathrm{ha}^{-1}$ of N, $14.41 \mathrm{~kg} \mathrm{ha}^{-1}$ of S, $10.30 \mathrm{~kg} \mathrm{ha}^{-1}$ of Ca, $8.34 \mathrm{~kg} \mathrm{ha}^{-1}$ of $\mathrm{P}$, and $6.33 \mathrm{~kg} \mathrm{ha}^{-1}$ of $\mathrm{Mg}$, and correspond to relative export of $18,17,11,8,8$, and $5 \%$, respectively, of the total accumulated by the pineapple plant.

\section{LITERATURE CITED}

AMORIM, A.V.; LACERDA, C.F.; MOURA, C.F.H. \& GOMES FILHO, E. Fruit size and quality of pineapples cv. Vitória in response to micronutrient doses and way of application and to soil covers. R. Bras. Frutic., 33:505-510, 2011.

AUGOSTINHO, L.M.D.; PRADO, R.M.; ROZANE, D.E. \& FREITAS, N. Acúmulo de massa seca e marcha de absorção de nutrientes em mudas de goiabeira 'Pedro Sato'. Bragantia, 67:577-585, 2008.

BAAFI, E.; QUANSAH, G.W.; BANFUL, B. \& MAC-AMOO, E.E.E. Effect of different combinations of nitrogen and potassium on fruit yield and quality of MD-2 pineapple in the forest ecozone of Ghana. Ghana J. Hortic., 7:35-43, 2009.

BALDOTTO, L.E.B.; BALDOTTO, M.A.; GIRO, V.B.; CANELLAS, L.P.; OLIVARES, F.L. \& BRESSAN-SITH, R. Desempenho do abacaxizeiro 'Vitória' em resposta à aplicação de ácidos húmicos durante a aclimatação. R. Bras. Ci. Solo, 33:979-990, 2009.

COELHO, R.I.; LOPES, J.C.; CARVALHO, A.J.C.D.; AMARAL, J.A.T.D. \& MATTA, F.D.P. Estado nutricional e características de crescimento do abacaxizeiro Jupi cultivado em Latossolo Amarelo distrófico em função da adubação com NPK. Ci. Agrotec., 31:1696-1701, 2007.

EMPRESA BRASILEIRA DE PESQUISA AGROPECUÁRIA EMBRAPA. Centro Nacional de Pesquisa de Solos. Sistema brasileiro de classificação de solos. 2.ed. Rio de Janeiro, Embrapa Solos, 2006. 306p.

EMPRESA BRASILEIRA DE PESQUISA AGROPECUÁRIA EMBRAPA. Centro Nacional de Pesquisa de Solos. Manual de métodos de análise de solo. 2.ed. Rio Janeiro, Embrapa Solos, 1997. 212p.

GRANGEIRO, L.C.; NEGREIROS, M.D.; SOUZA, D.B.; AZEVEDO, P.D.; OLIVEIRA, S.D. \& MEDEIROS, M.D. Acúmulo e exportação de nutrientes em beterraba. Ci. Agrotéc., 31:267-273, 2007.

GUARÇONI, A. \& VENTURA, J.A. Adubação NPK e o desenvolvimento, produtividade e qualidade dos frutos do abacaxi ‘GOLD'(MD-2). R. Bras. Ci. Solo, 35:1367-1376, 2011.

INSTITUTO NACIONAL DE METEOROLOGIA - INMET. Banco de dados meteorológicos para ensino e pesquisa. Disponível em: <http://www.inmet.gov.br/portal/ index.php?r= bdmep/bdmep>. Acesso em: 29 de set. de 2012 .

HIROCE, R.; BATAGLIA, O.C.; FURLANI, P.R.; FURLANI, A.M.C.; GIACOMELLI, E.J. \& GALLO, J.R. Composição química inorgânica do abacaxizeiro (Ananas comosus 'Cayenne') da região de Bebedouro, SP. Ci. Cult., 29:323326, 1977.
MALÉZIEUX, E. \& BARTHOLOMEW, D.P. Plant nutrition. In: BARTHOLOMEW, D.P.; PAUL, R.E. \& ROHRBACH, K.G., eds. The Pineapple: Botany, production and uses. Honolulu, CAB, 2003. p.143-165.

MARQUES, L.S.; ANDREOTTI, M.; BUZETTI, S.; TEIXEIRA FILHO, M.X.M. \& GARCIA, C.M.P. Análise química da folha "D" de abacaxizeiro cv. Smooth Cayenne antes e após a indução floral em função de doses e parcelamentos de nitrogênio. Biosci. J., 29:41-50, 2013.

MARTINEZ, H.E.P.; CARVALHO, J.G. \& SOUZA, R.B. Diagnose foliar. In: RIBEIRO, A.C.; GUIMARÃES, P.T.G. \& ALVAREZ V., V. H., eds. Recomendações para o uso de corretivos e fertilizantes em Minas Gerais. 5 Aproximação. Viçosa, MG, Universidade Federal de Viçosa, 1999. p.143-168.

MALAVOLTA, E.; VITTI, G.C. \& OLIVEIRA, S.A. Avaliação do estado nutricional de plantas: Princípios e aplicações. 2.ed. Piracicaba, Potafos, 1997. 319p.

NAHRAWI, H.; HUSNI, M.H.A.; OTHMAN, R. \& BAH, A. Decomposition of leaf and fine root residues of three different crop species in tropical peat under controlled condition. Malaysian J. Soil Sci., 15:63-74, 2011.

PAULA, M.B.; CARVALHO, J.G.; NOGUEIRA, F.D. \& SILVA, C.R.R. Exigências nutricionais do abacaxizeiro. Inf. Agropec., 11:27-32, 1985.

PY, C.; LACOEUILHE, J.J. \& TEISON, C. The pineapple: cultivation and uses. Paris, G.P. Maisonneuve et Larose, 1987. 568p.

RAMOS, M.J.M.; MONNERAT, P.H.; PINHO, L.G.R. \& SILVA, J.A. Deficiência de macronutrientes e de boro em abacaxizeiro 'Imperial': Composição mineral. R. Bras. Frutic., 33:261-271, 2011.

REINHARDT, D.H.; SOUZA, L.F.S. \& CABRAL, J.R.S. Abacaxi irrigado em condições semi-áridas. Cruz das Almas, Embrapa Mandioca e Fruticultura, 2001. 108p.

RIBEIRO, D.G.; VASCONCELLOS, M.A.S. \& ARAÚJO, A.P. Contribuição do sistema radicular de mudas micropropagadas na absorção de nitrogênio de abacaxizeiro cultivar Vitória. R. Bras. Frutic., 33:1240$1250,2011$.

SAMPAIO, A.C.; FUMIS, T.D.F. \& LEONEL, S. Crescimento vegetativo e características dos frutos de cinco cultivares de abacaxi na região de Bauru-SP. R. Bras. Frutic., 33:816$822,2011$.

SILVA, A.P.; ALVAREZ V., V.H.; SOUZA. A.P.; NEVES, J.C.L.; NOVAIS. R.F. \& DANTAS, J.P. Sistema de recomendação de fertilizantes e corretivos para a cultura do abacaxizeiro. R. Bras. Ci. Solo, 33:1269-1280, 2009

SOUZA, M.; GUIMARÃES, P.T.G.; CARVALHO, J.G. \& FRAGOAS, J.C. Abacaxizeiro. In: RIBEIRO, A.C.; GUIMARÃES, P.T.G. \& ALVAREZ V., V.H., eds. Recomendações para o uso de corretivos e fertilizantes em Minas Gerais - $5^{\text {a }}$ Aproximação. Viçosa, MG, Universidade Federal de Viçosa, 1999. p.216.

SPIRONELLO, A.; QUAGGIO, J.A.; TEIXEIRA, L.A.J.; FURLANI, P.R. \& SIGRIST, J.M.M. Pineapple yield and fruit quality effected by NPK fertilization in a tropical soil. R. Bras. Frutic., 26:155-159, 2004. 
TEIXEIRA, L.A.J.; QUAGGIO, J.A.; CANTARELLA, H. \& MELLIS, E.V. Potassium fertilization for pineapple: Effects on soil chemical properties and plant nutrition. R. Bras. Frutic., 33:627-636, 2011.
VENTURA, J.A.; COSTA, H. \& CAETANO, L.C. Abacaxi Vitória: Uma cultivar resistente à fusariose. R. Bras. Frutic., 31:931, 2009. 